\title{
Cluster formation of potential assessment for swine manure treatment and biogas generation in an experimental watershed in Rio Grande do Sul, Brazil
}

\author{
V. Schneider, N. Zanoni \& S. Carra \\ University of Caxias do Sul, Brazil
}

\begin{abstract}
This paper presents a proposal for collective systems for handling manure, also called clusters, and consequent generation of electricity from biogas, for a swine herd installed in 2012 in the municipalities of Serafina Corrêa and União da Serra, in the State of Rio Grande do Sul, Brazil. From the preparation of sand, hypsometry and slope maps for both municipalities associated with plotting the location of the swine herds, this work proposed five clusters where the waste of 8,660 animals are conducted entirely by gravity. The biogas generated in the anaerobic treatment is transformed into electrical energy could supply 285 homes whose average monthly consumption is $200 \mathrm{kWh}$ or can be inserted into the internal or external network of property, corroborating in extra income to swine farmers and the sustainability of the activity. From this objective, the job initiates a technical assessment in order to enable these collective treatment systems and reduce the environmental impacts generated by swine activity.

Keywords: swine farming, waste, clusters, biogas, power generation.
\end{abstract}

\section{Introduction}

Population growth demands greater food production and consequently the increase in the production of animal protein, especially the use of pork, beef and chicken. In this context, Brazil currently occupies fourth place in the production and export of pork and in 2015 should provide an approximate herd of 39.3 million animals, which will produce about 3.4 million tons of carcasses (USDA [1]). 
According to Kunz et al. [2], the tropical climate, low cost of labor, ease of handling and treatment of waste, benefited by large territorial dimensions and the large production of grains, such as corn and soybeans, makes Brazil one of the countries with the best conditions to increase the swine herd. In Rio Grande do Sul, the second largest creator of pigs in Brazil, swine activity is present in virtually all regions, although is more concentrated in the north and northeast, integrated proximity of processing industries (SEPLAG [3]) and associated with small farms, where livestock activity supplements income from agricultural activities.

The increase in density and pig population has caused serious environmental problems since, according Vanotti et al. [4] and Williams [5], the application of manure as a source of nutrient aggravates the emissions of volatile organic compounds, particulate matter, pathogens and odor. Furthermore, one of the issues is the evident contamination of surface and ground water and soil when waste is discarded without treatment (Peng [6] Riaño and García-González [7]). Hernandes and Schmidt [8] state that the lack of correct destination for the waste and pollution that can cause, if released, an excess in the soil are the main environmental problems faced by this activity.

According Rodriguez-Verde et al. [9], the use of anaerobic digesters sets up one of the most important techniques in the treatment of swine manure. This equipment is able to reduce contaminant power to mitigate the impact on soil, water and air. As a result of this process, there is the generation of products of interest such as biogas, which can be converted into electrical and/or thermal energy and the effluent from the digester, which can be used as agricultural fertilizer.

Considering the above, this paper aims to propose collective treatment systems of swine manure, also called clusters, aiming to transport manure using only gravity as the driving force, being used to generate electricity from biogas to the swine herd installed in the municipalities of Serafina Corrêa and União da Serra, in the northeastern state of Rio Grande do Sul, Brazil. Thus, it is expected to start a technical assessment in order to enable these collective treatment systems and reduce the environmental impacts generated by swine activity.

\section{Materials and methods}

In this study, we used project information of "Sanitation in Rural Areas evaluation of pig activities and impacts to water quality in the region spanning the COREDE Serra - projection scenarios and perspectives", started in 2012 and completed in 2014 by the Institute of Environmental Sanitation at the University of Caxias do Sul. The project quoted set up an experimental watershed considering the characteristics of use and land cover, soil science, hydrology, hypsometry, slope beyond the capacity of pigs.

The experimental basin is partially composed of four municipalities: Serafina Corrêa, Montauri, União da Serra and Guaporé, located in the watershed of the Guaporé River, in the northeastern state of Rio Grande do Sul. In these 
municipalities, information about the swine herd installed in 2012 was obtained from the local environmental agencies.

The location maps of pig farmers and slope in the experimental watershed were adapted from Schneider [10] and elaborated through ArcMap 10 software from the geographical coordinates of the pig farmers.

In this study we used the actual liquid waste generated by the confined animals, using as a basis the growth curve of the animal proposed by the Gompertz model, based on experimental weight gain data (de Freitas and Costa [11], Fialho [12] and de Freitas [13]). In quantifying the manure, BOD and nutrients per animal the information presented in Table 1 was used.

Table 1: Physical and chemical characteristics of swine manure produced per $1000 \mathrm{~kg}$ live weight.

\begin{tabular}{lc}
\hline \multicolumn{1}{c}{ Parameter } & Quantity \\
\hline Total volume $(\mathrm{L})$ & 84 \\
Urine $(\mathrm{L})$ & 39 \\
Specific mass $\left(\mathrm{kg} / \mathrm{m}^{3}\right)$ & 990 \\
Total solids $(\mathrm{kg})$ & 11 \\
Volatile solids $(\mathrm{kg})$ & 8.5 \\
BOD $(\mathrm{kg})$ & 3.1 \\
COD $(\mathrm{kg})$ & 8.4 \\
PH & 7.5 \\
Kjeldahl nitrogen $\left(\mathrm{N}_{\text {total }}\right)(\mathrm{kg})$ & 0.52 \\
Ammonia nitrogen $(\mathrm{kg})$ & 0.29 \\
Total phosphorous $(\mathrm{P})(\mathrm{kg})$ & 0.18 \\
Total potassium $(\mathrm{K})(\mathrm{kg})$ & 0.29 \\
\hline
\end{tabular}

Source: ASAE in Perdomo et al. [14].

For quantification of waste, BOD and nutrients (nitrogen, potassium and phosphorus), we used the average generation per kilogram of live animal, arranged by Perdomo et al. [14]. From the daily generation (DG), the total production per animal was calculated from birth to slaughter, considering a cycle of a 168 day period, the growth curve of Gompertz (de Freitas and Costa [11], Fialho [12] and de Freitas [13]).

Quantification of each component produced by the swine herd was obtained by using the GD of the sum to an animal according to the length of period, multiplied by the herd and the number of lots created in a year, thus obtaining the annual generation. 
The evaluation of the methane production potential from manure had reference to a methodology of the adjustment proposed by the National Biomass Reference Center - CENBIO in IPEA [15]. The estimate of biogas production was converted into electrical energy, calculated by adapting the method described by Junior and Domingues [16].

Considering the swine herds installed in the municipalities of União da Serra and Serafina Corrêa and its generated manure load, coupled with the geographic location of plotted herds in the topographic map, collective treatment of waste systems, also called clusters, was proposed, to generate energy from biogas.

\section{Results}

Hereafter are the results of the potential formation of collective systems for the treatment of swine manure, clusters associated with power generation from biogas in the municipalities of União da Serra and Serafina Corrêa.

\subsection{Assessment of the swine herd}

Figure 1 shows the delimitation of the experimental watershed of Arroio Lajeado Tacongava and its tributaries as well as the location of the swine herds.

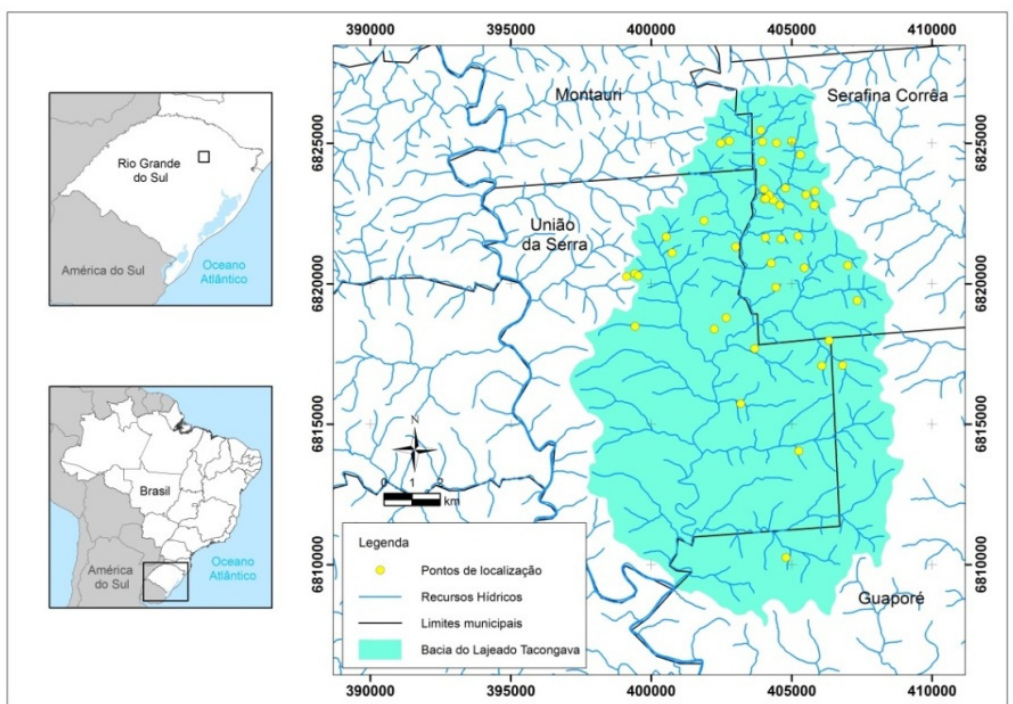

Figure 1: Experimental watershed and pig farmers' location. (Source: prepared by Geise Macedo dos Santos [17], adapted from Schneider [10].)

Figure 1 shows that there are 46 swine herd farms installed in the experimental watershed where almost all are allocated close to water resources. Note that the most significant concentration occurs in the municipalities of União da Serra and 
Serafina Corrêa with 15 and 26 pig farming units respectively, which justifies the approach of these municipalities in this study. Table 2 shows the number of animals in both municipalities in the respective stages of pig creation.

As noted in Table 2, the municipality of Serafina Corrêa has a total herd of 11,799 animals distributed in various stages of creation, where the finishing phase is the most significant. The municipality of União da Serra has 6,480 animals, all in the finishing phase. The total swine herd, considering both municipalities, is 18,279 animals.

Table 2: $\quad$ Total pigs in each phase.

\begin{tabular}{|c|c|c|}
\hline Creating phase & Serafina Corrêa & União da Serra \\
\hline Production unit piglets (sows) & 230 & - \\
\hline Sows full cycle & 50 & - \\
\hline Complete cycle & 1,560 & - \\
\hline Weaners & $369^{1}$ & - \\
\hline Finishing & $9,590^{2}$ & 6,480 \\
\hline Total & 11,799 & 6,480 \\
\hline
\end{tabular}

It is worth noting that the bibliography adopts different periods of animals remaining in the breeding sheds. In this work the weaners' time was defined as 45 days, equivalent to 8.1 lots per year and finishing pigs considered 95 days, totaling 3.84 lots per year.

The number of lots per year was achieved by dividing the number of days of the year by the number of days that the animal remains in the establishment. Thus to achieve the annual herd it is necessary to multiply the number of animals by the number of lots in the respective phase. For animals from complete cycle matrices the number of animals in the year is considered. However, the periods can vary according to the particularities of each integrator or property.

\subsection{Generation of manure, BOD and nutrients in the experimental watershed}

Table 3 shows the generation of waste, BOD and nutrients according to the cities.

As noted in Table 3, the city of Serafina Corrêa is responsible for generating $61.5 \%$ of the manure, resulting from the significant swine herd installed there. 
Table 3: Manure, BOD and nutrients generated in the experimental watershed in the period of one year.

\begin{tabular}{cccccc}
\hline Watershed & $\begin{array}{c}\text { Manure } \\
\text { (kg/year) }\end{array}$ & $\begin{array}{c}\text { BOD } \\
\text { (kg/year) }\end{array}$ & $\begin{array}{c}\text { Nitrogen } \\
\text { (kg/year) }\end{array}$ & $\begin{array}{c}\text { Potassium } \\
\text { (kg/year) }\end{array}$ & $\begin{array}{c}\text { Phophorous } \\
\text { (kg/year) }\end{array}$ \\
\hline $\begin{array}{c}\text { Serafina } \\
\text { Corrêa }\end{array}$ & $21,143,213$ & 816,390 & 136,942 & 47,402 & 50,035 \\
\hline $\begin{array}{c}\text { União da } \\
\text { Serra }\end{array}$ & $13,248,219$ & 488,922 & 82,012 & 28,389 & 29,996 \\
\hline Total & $\mathbf{3 4 , 3 9 1 , 4 3 2}$ & $\mathbf{1 , 3 0 5 , 3 1 2}$ & $\mathbf{2 1 8 , 9 5 4}$ & $\mathbf{7 5 , 7 9 1}$ & $\mathbf{8 0 , 0 3 1}$ \\
\hline
\end{tabular}

\subsection{Proposition of collective systems of waste treatment (clusters)}

Through the slope map it was possible to evaluate the possibility of formation of collective manure treatment systems. Figure 2 shows the slope map with the location of the swine herds in the city of Serafina Corrêa, where it is noted that there is a possibility of formation of three clusters of pig farmers. According to the location of points, there is sharp relief that favors manure transport by gravity, without needing investments in booster pumps or other technologies.

Figure 3 shows the slope map with the location of the swine herds in the municipality of União da Serra.

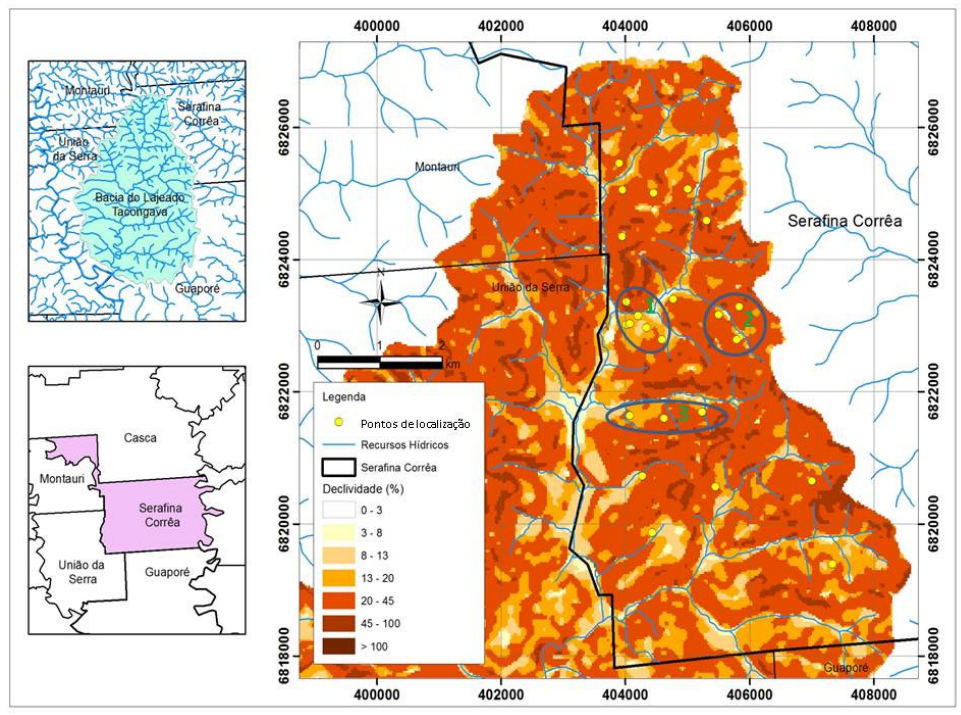

Figure 2: Slope map and location of pig farmers in Serafina Corrêa. (Source: prepared by Geise Macedo dos Santos [17] adapted from Schneider [10]). 


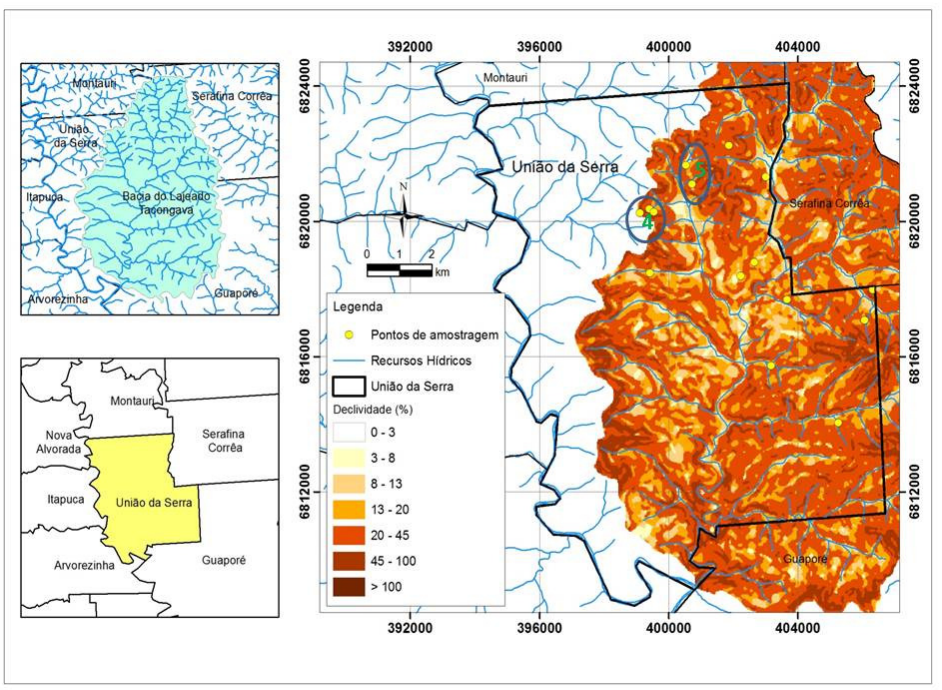

Figure 3: Slope map and location of pig farmers at União da Serra. (Source: prepared by Geise Macedo dos Santos [17] adapted from Schneider [10].)

According to Figures 2 and 3, there is the possibility of forming 5 clusters of pig farmers, which enables driving of gravity for a single manure treatment system in each cluster. This helps reduce installation and maintenance costs of the equipment. Table 4 shows the collective treatment systems proposed with its capacity of pigs.

Table 4: Clusters of pig farmers proposed for the municipalities of Serafina Corrêa and União da Serra.

\begin{tabular}{|c|c|c|c|c|c|}
\hline & Finishing & $\begin{array}{c}\text { Piglet } \\
\text { production } \\
\text { unit (sows) }\end{array}$ & $\begin{array}{l}\text { Complete } \\
\text { cycle }\end{array}$ & Pig farmers & Cities \\
\hline Cluster 1 & 2,900 & 250 & 1,560 & 7 & $\begin{array}{l}\text { Serafina } \\
\text { Corrêa }\end{array}$ \\
\hline Cluster 2 & 1,030 & - & - & 4 & $\begin{array}{l}\text { Serafina } \\
\text { Corrêa }\end{array}$ \\
\hline Cluster 3 & 860 & - & - & 3 & $\begin{array}{l}\text { Serafina } \\
\text { Corrêa }\end{array}$ \\
\hline Cluster 4 & 1,120 & - & - & 3 & $\begin{array}{l}\text { União da } \\
\text { Serra }\end{array}$ \\
\hline Cluster 5 & 940 & - & - & 2 & $\begin{array}{l}\text { União da } \\
\text { Serra }\end{array}$ \\
\hline
\end{tabular}

- No animals in this phase in the cluster. 
According to Table 5, cluster 1 is the most significant and involves 7 pig farmers, including a herd of 2,900 animals in finishing, 200 sows in the piglet production unit and 1,560 animals in full cycle. After weaning, the piglets in the piglet production unit are referred to other properties for growing and finishing.

For each cluster, the generation of manure, BOD, nutrients and potential of biogas generation for later use in the production of electricity was calculated. These results are shown in Table 5.

Table 5: $\quad$ Parameters analyzed in clusters.

\begin{tabular}{lcccccc}
\hline $\begin{array}{l}\text { Parameters } \\
\text { analyzed }\end{array}$ & Cluster 1 & Cluster 2 & Cluster 3 & Cluster 4 & Cluster 5 & Total \\
\hline $\begin{array}{l}\text { Manure } \\
\text { (ton/year) }\end{array}$ & 8,008 & 2,243 & 1,758 & 2,289 & 1,921 & $\mathbf{1 6 , 2 1 9}$ \\
\hline $\begin{array}{l}\text { BOD } \\
\text { (kg/year) }\end{array}$ & 327,806 & 86,776 & 64,887 & 84,505 & 70,923 & $\mathbf{6 3 4 , 8 9 7}$ \\
\hline $\begin{array}{l}\text { Biogas } \\
\text { (m/year) }\end{array}$ & 368,603 & 103,279 & 80,923 & 105,389 & 88,451 & $\mathbf{7 4 6 , 6 4 5}$ \\
\hline $\begin{array}{l}\text { Electricity } \\
\text { (kWh/year) }\end{array}$ & 339,156 & 95,028 & 74,458 & 96,969 & 81,385 & $\mathbf{6 8 6 , 9 9 6}$ \\
\hline $\begin{array}{l}\text { Nitrogen } \\
\text { (kg/year) }\end{array}$ & 20,086 & 5,311 & 10,884 & 14,175 & 11,896 & $\mathbf{6 2 , 5 3 2}$ \\
\hline $\begin{array}{l}\text { Phosphorous } \\
\text { (kg/year) }\end{array}$ & 19,034 & 5,032 & 3,767 & 4,906 & 4,118 & $\mathbf{3 6 , 8 5 7}$ \\
\hline $\begin{array}{l}\text { Potassium } \\
\text { (kg/year) }\end{array}$ & 20,086 & 5,311 & 3,976 & 5,179 & 4,346 & $\mathbf{3 8 , 8 9 8}$ \\
\hline
\end{tabular}

As shown in Table 6, 16,219 tons of manure are produced in clusters, containing 634.8 tons of BOD and a total of 138.2 tons of nutrients (nitrogen, phosphorus and potassium). In this way, 746,000 cubic meters of biogas can be generated annually. If the biogas was transformed into electricity, it could generate 686 MWh of electricity and be enough to supply 285 houses whose average monthly consumption is $200 \mathrm{kWh}$.

\section{Conclusion}

From the results obtained, the viability of forming five clusters to treatment of pig manure was observed, using only gravity as the driving force for transporting the manure to the treatment system. Among the products of the treatment of waste has been the generation of biogas, which is converted into electrical energy and can be inserted into the domestic distribution network or external to the property, corroborating in extra income for pig farmers and the sustainability of the activity.

In addition to the electrical energy, thermal energy could be generated to be used in the properties to maintain the temperature inside the sheds during the 
winter but during the summer there could be an excess of biogas. Therefore, in this work, we opted for the generation of electricity during the year.

In these clusters, with the generation of biogas and subsequent transformation into electricity, it would be possible to supply 285 homes for a year considering an average monthly consumption of $200 \mathrm{kWh}$. However, more studies are necessary about the economic viability, to assess the initial investment and the return time of the proposed investment.

It is worth noting that to get more accurate results it is necessary to work with experimental data generated in the laboratory or in a pilot study for each parameter analyzed, considering that there are variations according to the region's climate as well as small variations in the composition of the manure, which directly affects digester performance. With respect to the calculations in this work, a dilution of the waste was not considered because it could vary in the pig properties.

\section{References}

[1] USDA. Production and Trade of All Meats to Expand in 2016. Livestock and Poultry: world markets and trade: United States Department of Agriculture 2015.

[2] Kunz, A.; Higarashi, M. M.; Oliveira, P. A. D. Tecnologias de manejo e tratamento de dejetos de suínos estudadas no Brasil. Cadernos de Ciência \& Tecnologia, v. 22, n. 3, pp. 651-665, 2005. ISSN 0104-1096.

[3] SEPLAG. Atlas socioeconômico Rio Grande do Sul. Suínos. Secretaria de Planejamento, Gestão e Participação Cidadã. 2013.

[4] Vanotti, M.; Szogi, A.; Vives, C. Greenhouse gas emission reduction and environmental quality improvement from implementation of aerobic waste treatment systems in swine farms. Waste Management, v. 28, n. 4, pp. 759766, 2008. ISSN 0956-053X.

[5] Williams, C. Technologies to mitigate enviromental impact of swine production. Revista Brasileira de Zootecnia, v. 37, n. SPE, pp. 253-259, 2008. ISSN 1516-3598.

[6] Peng, J. Environment concerns and waste management strategies of pig production in China. 2014 ADSA-ASAS-CSAS Joint Annual Meeting, 2014. Asas.

[7] Riaño, B.; García-González, M. Greenhouse gas emissions of an on-farm swine manure treatment plant-comparison with conventional storage in anaerobic tanks. Journal of Cleaner Production, 2014. ISSN 0959-6526.

[8] Hernandes, J.F. \& Schmidt, V. (2010) Impacto ambiental da suinocultura em granjas de porte médio a excepcional no Vale do Taquari-RS. Revista de Gestão Social e Ambiental, v. 4, n. 3, pp. 18-31.

[9] Rodriguez-Verde, I. et al. Assessing anaerobic co-digestion of pig manure with agroindustrial wastes: The link between environmental impacts and operational parameters. Science of The Total Environment, v. 497, pp. 475483, 2014. ISSN 0048-9697. 
[10] Schneider, V. E. Avaliação das águas superficiais e subterrâneas em municípios da serra: Relatório final. Universidade de Caxias do Sul. Caxias do Sul. 2011

[11] de Freitas, A. R.; Costa, C. N. Estimativa do crescimento de suínos machos através de modelo matemático. Brasília: EMBRAPA-CNPSA, 1982.

[12] Fialho, F. B. Interpretação da curva de crescimento de Gompertz. Embrapa Suínos e Aves, pp. 1-4, 1999.

[13] de Freitas, A. R. Curvas de crescimento na produção animal. R. Bras. Zootec, v. 34, n. 3, pp. 786-795, 2005.

[14] Perdomo, C. C.; de Lima, G. J.; Nones, K. Produção de suínos e meio ambiente. Sistema, v. 1995, p. 2000, 1990.

[15] IPEA. Diagnóstico dos Resíduos Orgânicos do Setor Agrossilvopastoril e Agroindústrias Associadas. Brasília: Instituto de Pesquisa Econômica Aplicada (IPEA) 2012.

[16] Junior, W. B. G.; Domingues, E. G. Análise de Viabilidade Econômica do Aproveitamento Energético do Biogás como Energia Renovável em Granjas de Suínos. Goiânia 2010.

[17] Dos Santos, G. M. Mapas da bacia experimental: arroio Tacongava. ArcMap 10. Caxias do Sul: Universidade de Caxias do Sul 2015. 